\title{
Possibilities of Reducing Energy Consumption by Optimization of Ground Source Heat Pump Systems in Babylon, Iraq
}

\author{
Jenny Lindblom, Nadhir Al-Ansari, Qais Al-Madhlom \\ Lulea University of Technology, Lulea, Sweden \\ Email: Jenny.Lindblom@ltu.se,nadhir.alansari@ltu.se,qais.al-madhlom@ltu.se
}

Received 15 February 2016; accepted 25 March 2016; published 28 March 2016

Copyright (C) 2016 by authors and Scientific Research Publishing Inc.

This work is licensed under the Creative Commons Attribution International License (CC BY). http://creativecommons.org/licenses/by/4.0/

cc) (7)

Open Access

\begin{abstract}
Iraq is located in the Middle East with an area that reaches $437,072 \mathrm{~km}^{2}$ and a population of about 36 million. This country is suffering from severe electricity shortage problems which are expected to increase with time. In this research, an attempt is made to minimize this problem by combining the borehole thermal energy storage (BTES) with a heat pump, the indoor temperature of a residential building or other facility may be increased or reduced beyond the temperature interval of the heat carrier fluid. Due to the relatively high ground temperature in Middle Eastern countries, the seasonal thermal energy storages (STES) and ground source heat pump (GSHP) systems have a remarkable potential, partly because the reduced thermal losses from the underground storage and the expected high COP (ratio of thermal energy gain to required driving energy (electricity)) of a heat pump, partly because of the potential for using STES directly for heating and cooling. In this research, groundwater conditions of Babylon city in Iraq were investigated to evaluate the possibility of using GSHP to reduce energy consumption. It is believed that such system will reduce consumed energy by about $60 \%$.
\end{abstract}

\section{Keywords}

Ground Source Heat Pump, Seasonal Thermal Energy Storages, Energy Saving, Babylon, Iraq

\section{Introduction}

Iraq is located in the Middle East region with an area that reaches 437,072 $\mathrm{km}^{2}$ (Figure 1). The population of Iraq reaches 36 million. The climate of the country is hot arid with subtropical influence. The temperature during summer is usually above $40^{\circ} \mathrm{C}$ as an average and it exceeds $50^{\circ} \mathrm{C}$ during the day in July and August. 


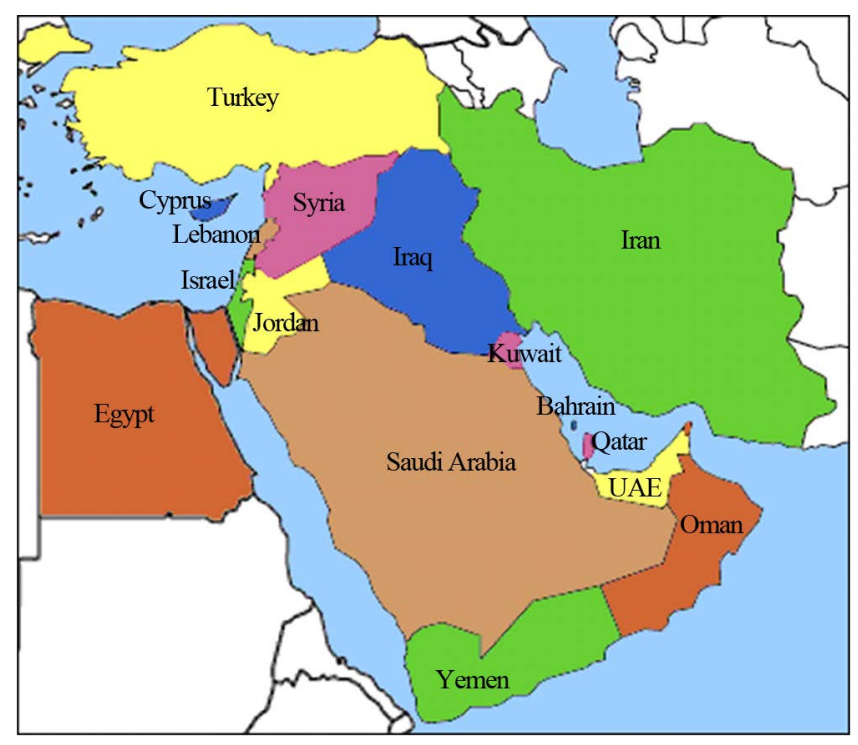

Figure 1. Location map of Iraq.

During winter the average temperature during the day is about $15^{\circ} \mathrm{C}$ and falls below zero at some nights.

Recent years indicated that the use of electricity is increasing for heating and cooling purposes. The electricity situation in Iraq is very poor since the bombing of the electricity generation plants during Gulf War I and II. For this reason Iraq, outside is autonomous Kurdish region, cannot guarantee its people a reliable electricity supply for a whole day. Iraq capacity of generating electricity is about 13 Gigawatts (nearly a third from Kurdistan) and this is still a quarter short of demand. It is assumed that the demand will reach about 42 Gigawatts by 2030 [1]. About $79 \%$ of the electricity is domestically consumed. In 2013 the output of the electricity sector in Iraq averages about 10,000 MW [2]. It should be mentioned however that, the demand is 14,000 MW. Iraq, cannot guarantee its people a reliable electricity supply for a whole day. It imports gas from neighboring Iran at high European prices and electricity from Turkish barges in the Gulf. Many Iraqis run their own generators, which account for $8 \%$ of the country's total electricity supply and can cost a family as much as $\$ 1000$ a month (a sixth of average annual income) [1]. A number of factories (about 35,000) have been shut down the last 20 years, leaving almost seven million people without jobs [3]. To overcome the shortage it costs Iraq $\$ 40$ billion a year [1].

There is no accurate estimate for actual electricity demand due to its suppression by institutional and economic constraints on consumption and the lack of accurate historical data since the 1990s [4]. In two recent studies, [4] estimated the demand between 50 and 70 percent higher than originally anticipated by the Iraqi Government (Figure 2), taking into account factors such as shifting demographics and suppressed demand. Total peak demand is likely to reach 50,000 to 60,000 MW by 2030 while the Iraqi Government forecasts peak demand as a mere 35,000 MW [4]. Continuous population growth (Figure 3) and the substantial jump in GDP growth after 2003, mainly due to the increase in crude oil prices, have contributed to the increase in the demand for electricity (Figure 4) [4]. Almintor [5] reported an example of one of the citizens in Babylon where he uses his own gasoline-powered generator, which produces 10 amps for six hours a day. The second source of electricity is the neighborhood's generator supplying 20 amps for nearly 10 hours a day; then the rest of the day is supplied by the government. The Iraqi Government is still struggling to restore the electricity [6].

In view of the above, it is of prime importance to reduce the energy consumption without affecting the standard of living. In this research, the optimization of ground source heat pump systems is to be demonstrated for Babylon Governorate. It is believed that this approach will reduce tremendously the energy loss in heating and cooling.

\section{Study Area}

Babylon Governorate is situated in the middle of Iraq about $100 \mathrm{~km}$ to the northest of the Iraqi capital, Baghdad [7], between latitude $32^{\circ} 5^{\prime} 41^{\prime \prime} \mathrm{N}$ and $33^{\circ} 7^{\prime} 36^{\prime \prime} \mathrm{N}$, and longitude $44^{\circ} 2^{\prime} 43^{\prime \prime} \mathrm{E}$ and $45^{\circ} 12^{\prime} 11^{\prime \prime E ~(F i g u r e ~ 5) . ~ I t ~ h o u s e s ~}$ one of the most famous cities of the ancient world, the city of Babylon was built 4100 years ago, and the city 


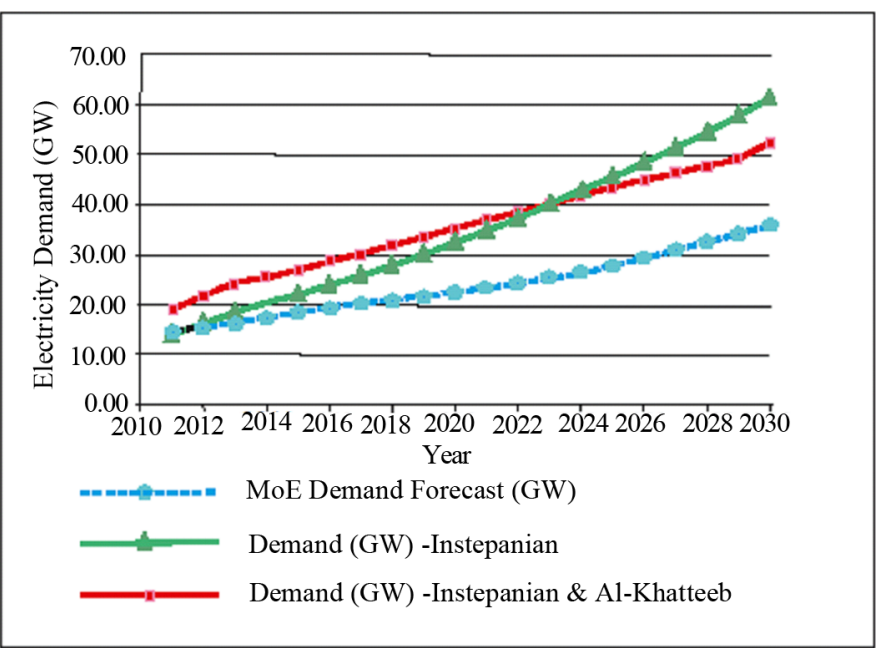

Figure 2. Electricity demand [4].

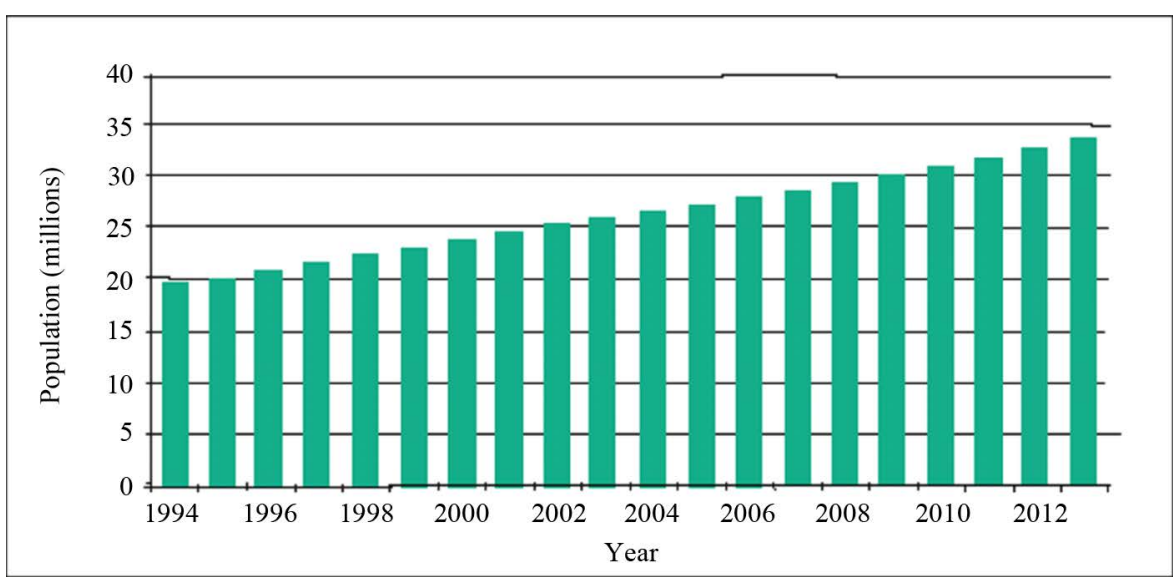

Figure 3. Population growth rate [4].

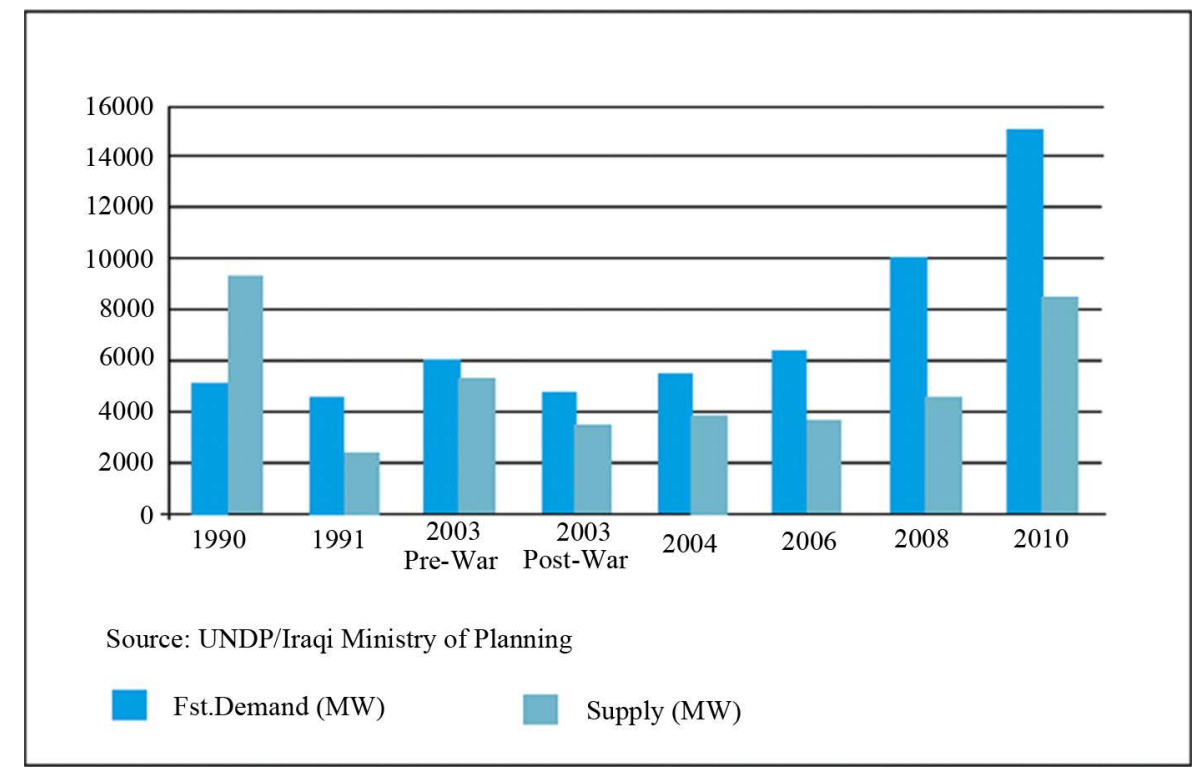

Figure 4. Electricity supply/demand 1991-2010 [4]. 


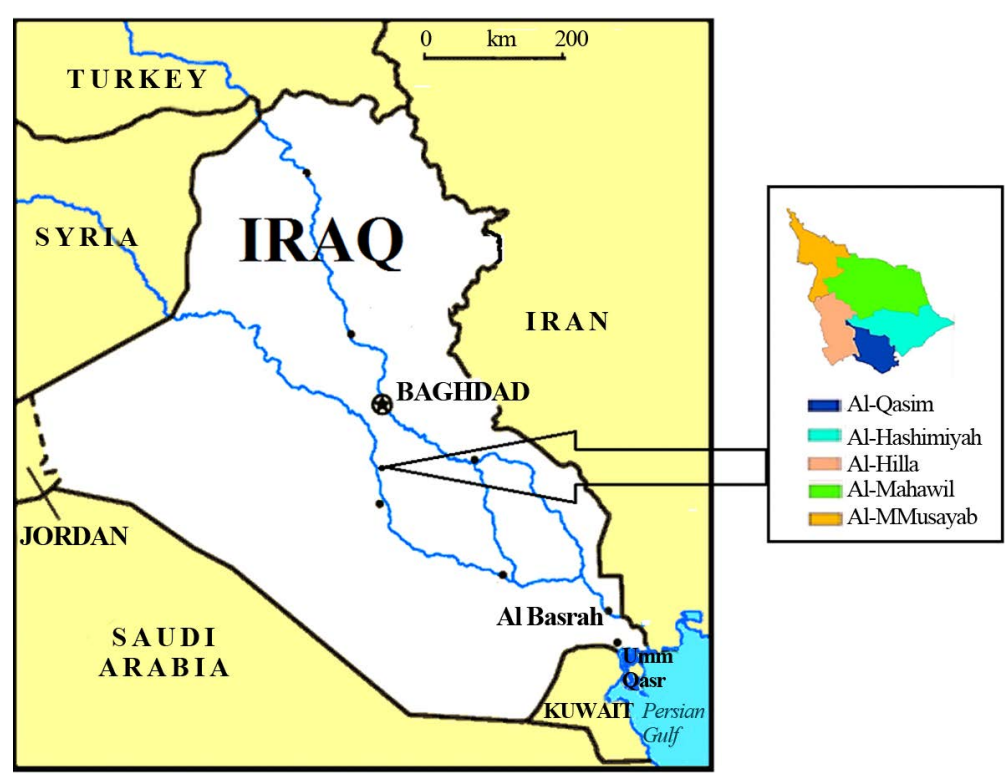

Figure 5. Map of Babylon Governorate.

was the power center of an expansive and influential empire. Babylon Governorate has a population of about 1,974,490 inhabitants distributed throughout sixteen cities, as shown in the Figure 6 [8]. The governorate is divided administratively into five major cities, referred to as Qadhaa and these cities are further divided into sixteen smaller cities called Nahiah. The administrative units of Babylon Governorate and their area are shown in Figure 7 and Figure 8, according to [9]. The governorate is characterized by relatively flat inclining land. The northern part of the governorate rises to approximately $60 \mathrm{~m}$ above sea level and falls to approximately $20 \mathrm{~m}$ over sea level in the southern part. This gradual decline is broken by a specific area of Al-Iskandariyah Nahiah, in the north of the governorate, which rises between 35 - $45 \mathrm{~m}$ above sea level. The land is fertile because Shatt Al-Hillah River passes through most cities in Babylon Governorate. The river branches off from the Euphrates River at the town of Sadah Al-Hindiah in the north of governorate and forms an important part of the beautiful scenery that is a feature of this governorate [9]. The governorate is characterized by its desert climate. The temperature fluctuates dramatically between day and night also with the changing seasons. Temperatures during the summer season can reach $45^{\circ} \mathrm{C}-50^{\circ} \mathrm{C}$ with 12 hours of sunlight/day and usually no precipitation. The winter is cold and rainy. There is 6.2 hours/day of sunlight with temperatures generally remaining above zero $0^{\circ} \mathrm{C}$ although on some nights they can fall below freezing. Precipitation falls at an average rate of $50-200 \mathrm{~mm} /$ year, which considered very low [7] [9].

\section{Groundwater Conditions}

Mesopotamian plain is a topographically flat plain. The slope is gentle from Baghdad to Basrah, but it gently undulated north of Baghdad. The elevation ranges from 150 to 3 meters above sea level. This region covers the area bounded by the Rivers Tigris and Euphrates south of Baghdad to the Gulf (Figure 9). The groundwater in this region is usually found within the recent alluvial deposits. The Tigris and Euphrates are the main source for groundwater in this region. The salinity varies with depth where it is of the order of $3500 \mathrm{ppm}$ at depths less than $20 \mathrm{~m}$ while it reaches $20,000 \mathrm{ppm}$ at greater depths, the groundwater table is very shallow near the ground level. In restricted areas fresh water of very good quality can be found overlying saline groundwater. Quaternary sediments (alternation of clay, silty clay, clayey silt, silt, sand and gravel) cover this area.

The general groundwater flow in the central part of the Mesopotamian plain is towards southeast with some local divergences to the east and south (Figure 10). Groundwater recharge is by percolation of surface water from rivers, streams, infiltration of rain and Irrigation water [10]. Araim [11] and Al-Jiburi [12] stated that another source of recharge is possibly in form of lateral and upward leakage from the groundwater of carbonate aquifers at the western part of the Mesopotamia Plain, whereas the natural discharge is mainly in the form of evapotranspiration [10]. Influent river phenomenon exists along the left bank of Euphrates River, as well as along 


\begin{tabular}{|c|c|c|c|c|}
\hline $\begin{array}{l}\text { Al-Qasim } \\
\text { Qadaa }\end{array}$ & $\begin{array}{l}\text { Al-Hashimiyah } \\
\text { Qadaa }\end{array}$ & $\begin{array}{l}\text { Al-Mahawil } \\
\text { Qadaa }\end{array}$ & $\begin{array}{l}\text { Al-Musayyab } \\
\text { Qadaa }\end{array}$ & $\begin{array}{l}\text { Al-Hillah } \\
\text { Qadaa }\end{array}$ \\
\hline $\begin{array}{c}\text { Al-Qasim } \\
147335 \\
\end{array}$ & $\begin{array}{c}\text { Al-Hashimiyah } \\
\mathbf{4 5 3 7 7}\end{array}$ & $\begin{array}{c}\text { Al-Mahawil } \\
115794\end{array}$ & $\begin{array}{c}\text { Al-Musayyab } \\
\mathbf{5 2 2 8 0}\end{array}$ & $\begin{array}{c}\text { Al-Hillah } \\
556840\end{array}$ \\
\hline \multirow[t]{3}{*}{$\begin{array}{l}\text { Al-Talyaah } \\
38526\end{array}$} & $\begin{array}{c}\text { Al-Shomaly } \\
88403\end{array}$ & $\begin{array}{c}\text { Al-Neel } \\
59178\end{array}$ & $\begin{array}{c}\text { Al-Iskandariyah } \\
156669\end{array}$ & $\begin{array}{l}\text { Al-Kifil } \\
140367\end{array}$ \\
\hline & \multirow[t]{2}{*}{$\begin{array}{c}\text { Al-Medhatyah } \\
136240\end{array}$} & $\begin{array}{c}\text { Al-Imam } \\
36196 \\
\end{array}$ & $\begin{array}{c}\text { Al-Sadah } \\
117948\end{array}$ & \multirow{2}{*}{$\begin{array}{c}\text { Abi-Ghraq } \\
110570\end{array}$} \\
\hline & & $\begin{array}{c}\text { Al-Mashroa } \\
124980\end{array}$ & $\begin{array}{c}\text { Jurf Al-Sakhar } \\
47787\end{array}$ & \\
\hline
\end{tabular}

Figure 6. Administrative units of Babylon Governorate and its population/(1000) [8].

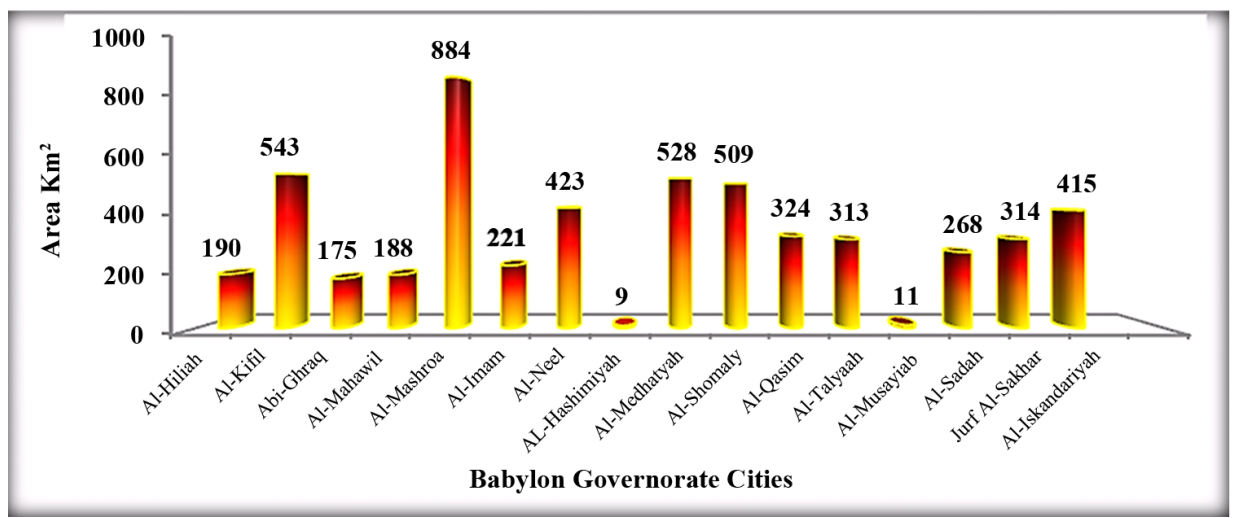

Figure 7. Cities area of Babylon Governorate [9].

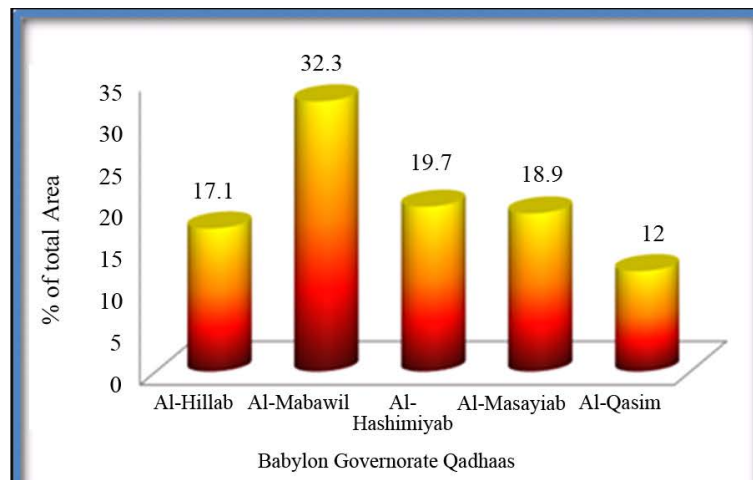

(a)

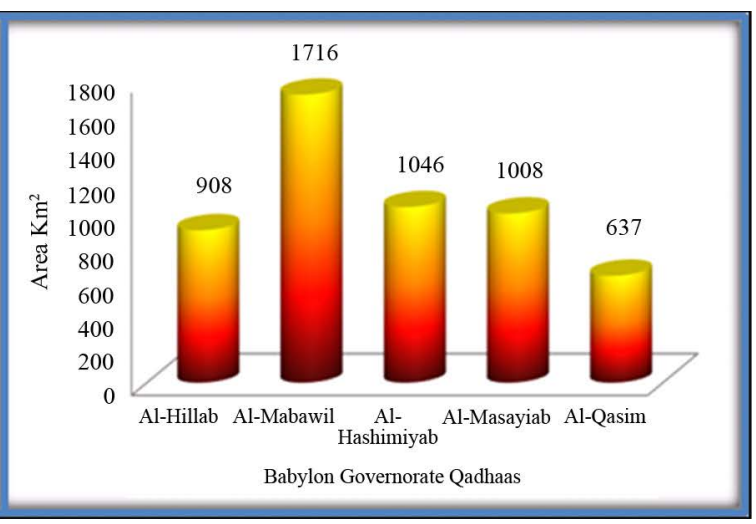

(b)

Figure 8. (a) proportion of Qadhaas’ area; (b) The total area for each Qadhaa in Babylon Governorate.

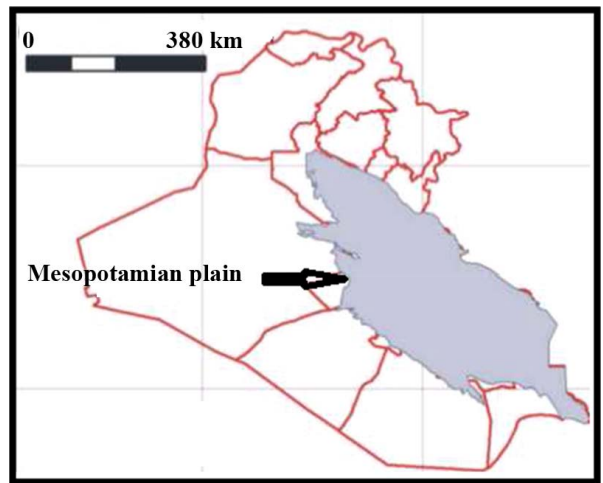

Figure 9. Location of Mesopotamian plain. 


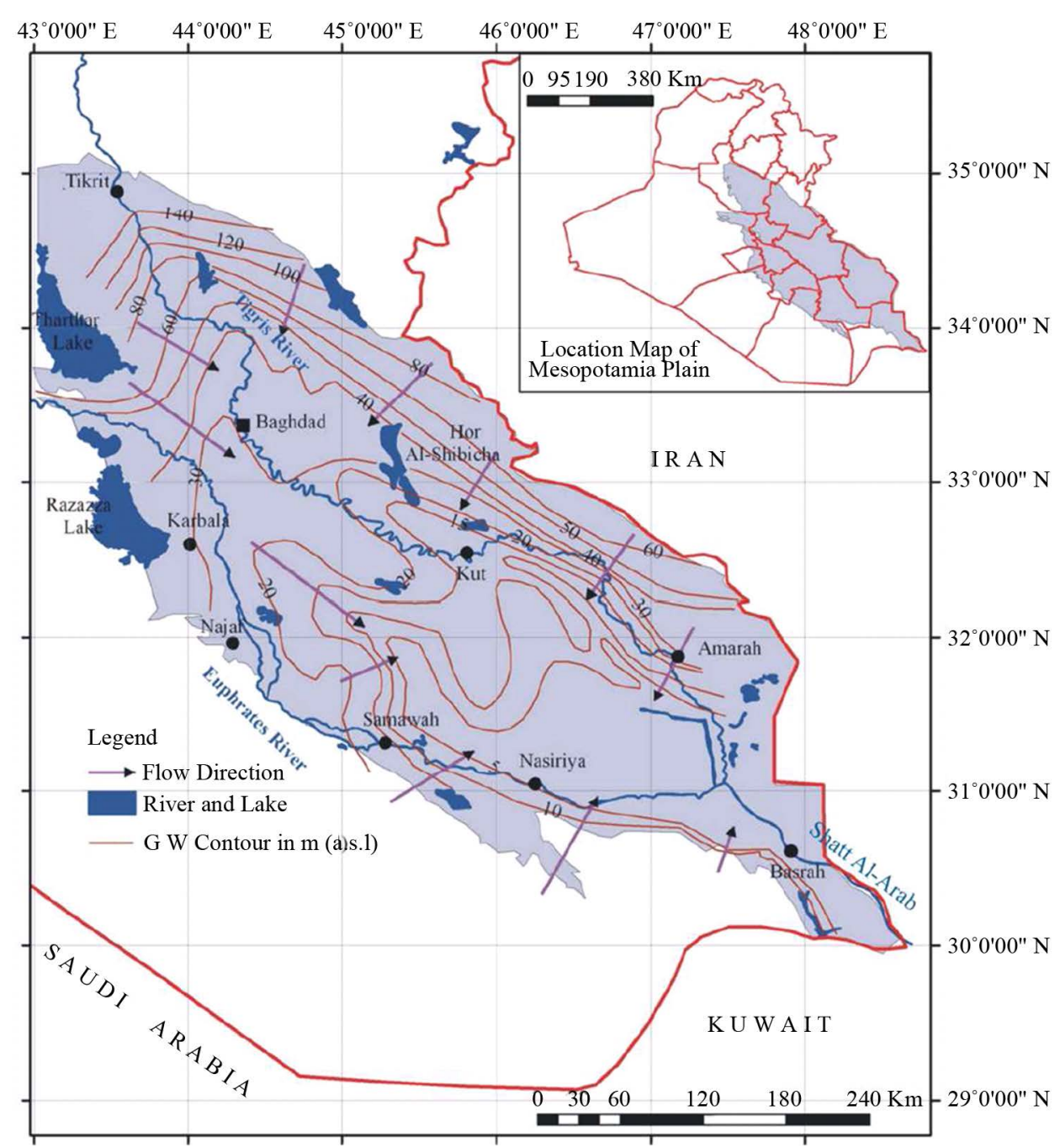

Figure 10. Hydrogeological map of the Mesopotamia Plain, shows static water level and direction of the groundwater flow (after [10]).

both sides of Al-Hilla River [10]. Transmissivity and permeability ranges from 10 to $165 \mathrm{~m}^{2} /$ day and 1 to 27 $\mathrm{m} /$ day respectively [10]. The water is maily chloridic with sulphates and its total dissolved solids ranges from $<1000$ to $422,000 \mathrm{mg} / \mathrm{l}$ (Figure 11) [10]. At Babylon Governorate, the data collected from 130 groundwater wells (Figure 12) indicated that the dominant water table depth is ranging from about 2 to 4 meters (Figure 13) while the permeability ranges from 0 to $2.9 \mathrm{~m} /$ day (Figure 14).

\section{Seasonal Thermal Energy Storage}

Seasonal thermal energy storages (STES) are designed for storing thermal energy from one season to another. During winter, heat is extracted by circulating a cool heat carrier through the storage. The heat carrier extracts thermal energy from the warmer storage volume, and transports the absorbed energy to the recipient at the ground surface. During the summer months, the system can be reversed, so that the heat carrier absorbs indoor heat, and releases it to the underground storage, which is thereby recharged [15].

One of the most commonly used STES today is the borehole thermal energy storage (BTES), in which one or more boreholes of $0.10-0.15 \mathrm{~m}$ in diameter are drilled vertically into the bedrock to $50-300$ meters depth [13]. A U-shaped plastic pipe is inserted into each borehole, through which a heat carrier fluid is circulated. The space between the U-pipe and ground may be grouted, or filled with naturally occurring groundwater [14]. The BTES can when necessary be charged with excess heat up to temperatures of about $85^{\circ} \mathrm{C}$, which is the 


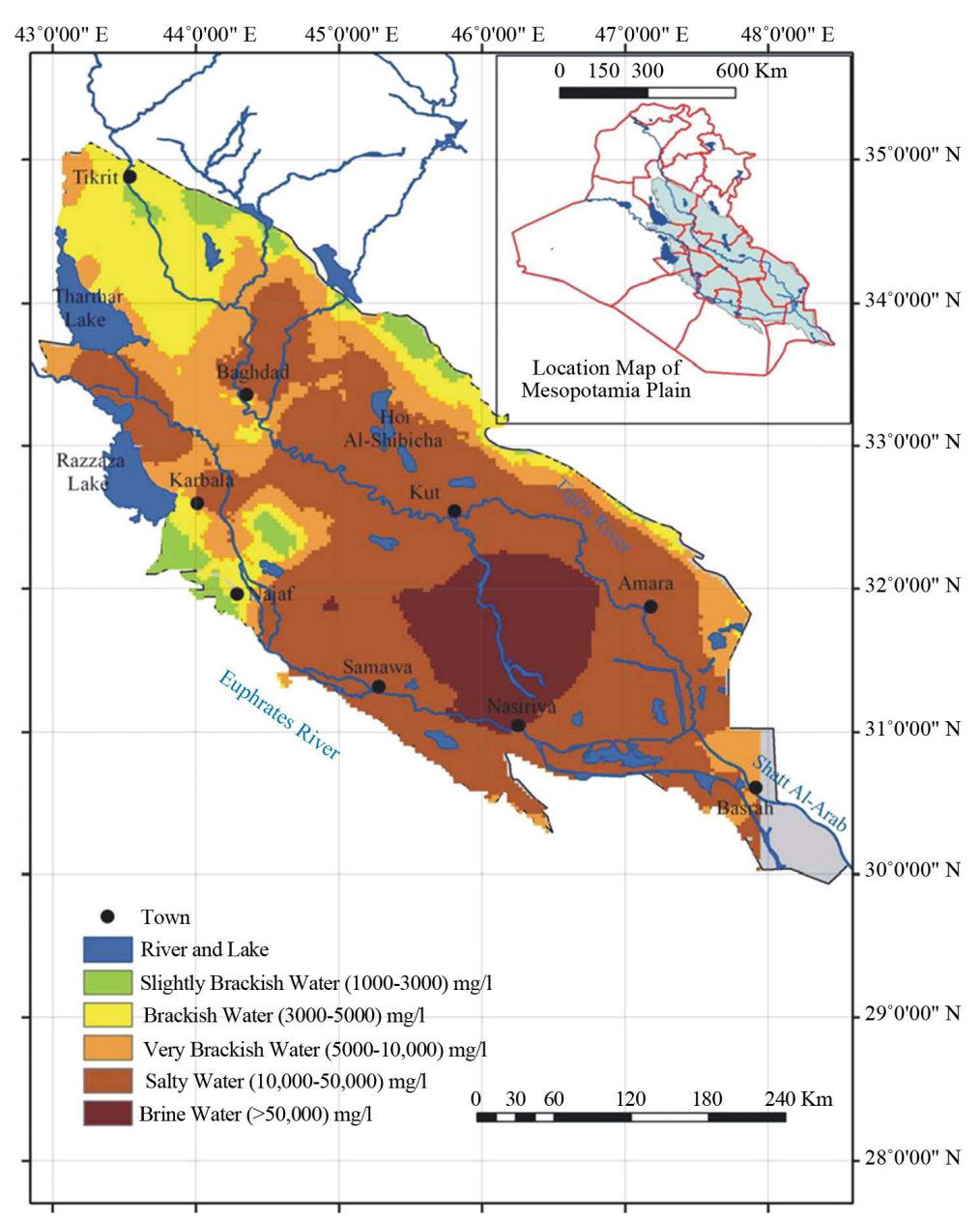

Figure 11. Hydro-chemical map of Mesopotamian plain (after [10]).

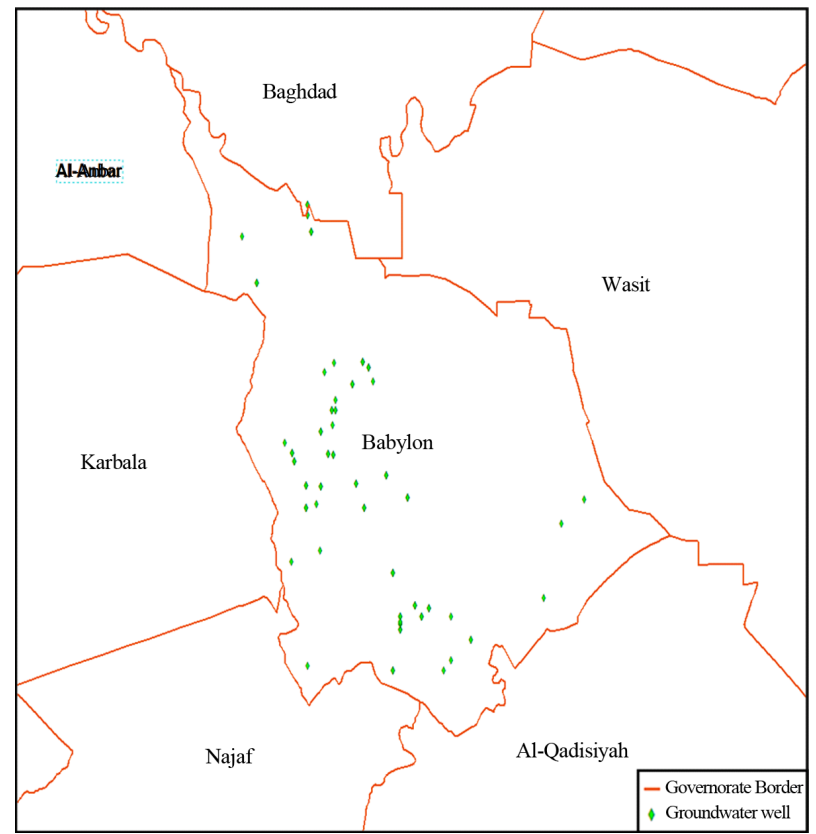

Figure 12. Location of groundwater wells in Babylon Governorate. 


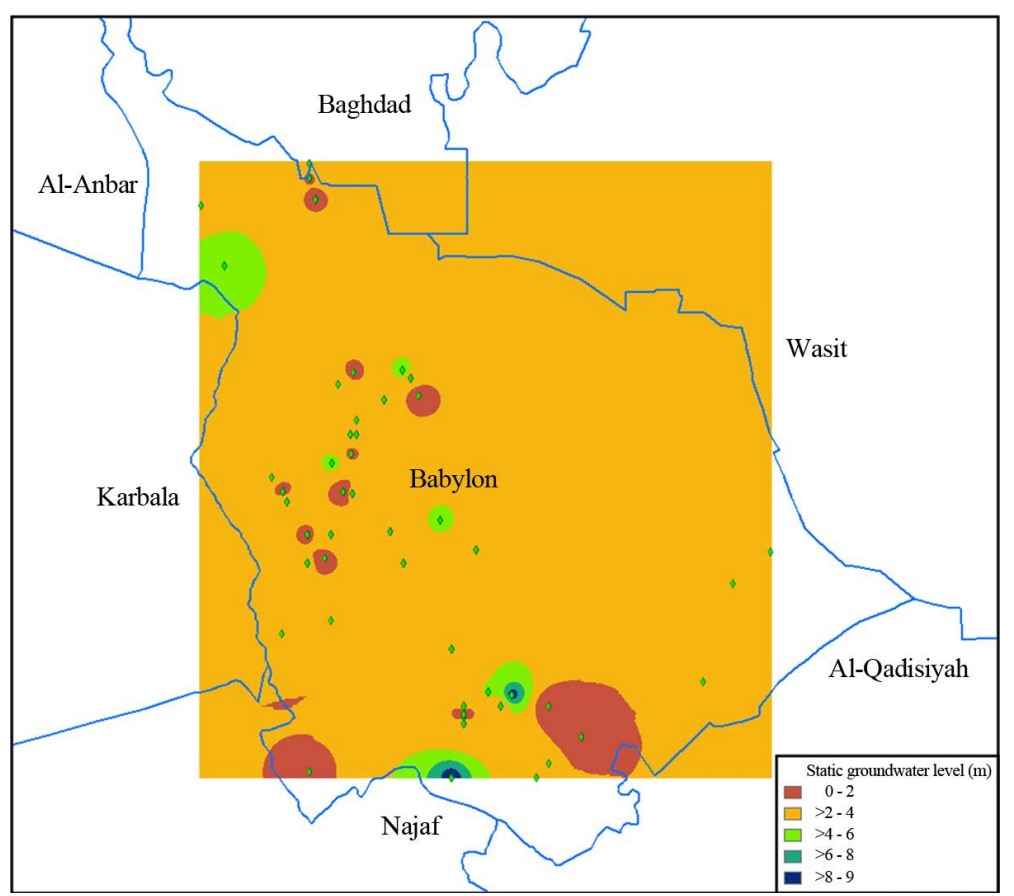

Figure 13. Static groundwater level (m) at Babylon Governorate.

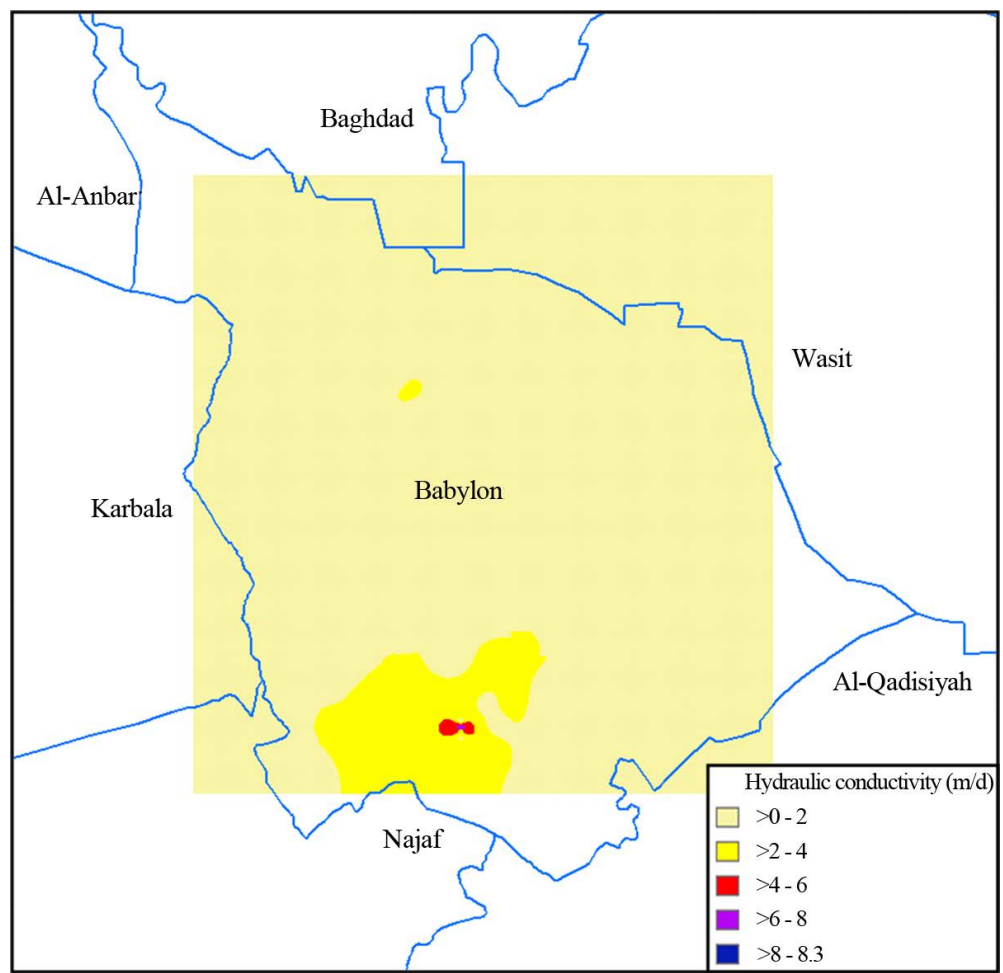

Figure 14. Permeability (m/day) of groundwater aquifers at Babylon Governorate.

critical temperature of the plastic pipes in commercial use today [16]. BTES has become very popular in many countries in applications ranging from single family house systems to large district heating and cooling systems. Sweden is one of the world leading countries in BTES installations, supplying up to $20 \%$ of the heating demand [17]. As BTES can be constructed below buildings, parking lots, etc., the technology is viable even in densely 
populated urban areas. The very long life expectancy of at least 100 years is another advantage of this technology [16].

By combining the BTES with a heat pump, the indoor temperature of a residential building or other facility may be increased or reduced beyond the temperature interval of the heat carrier fluid (Figure 15). These so called ground source heat pump (GSHP) systems are generally associated with very high thermal performance compared to conventional heating and cooling systems, even compared with other heat pump systems. In Sweden, a GSHP installation designed for a single-family house reduces the electricity consumption between $64 \%-80 \%$, compared to electrical radiators, according to the Swedish Energy Agency [18] [19]. Due to the warmer climate in Iraq, heat pump performance (COP) is expected to be higher than what is achieved in Sweden. In a study performed by [20] of the potential for GSHP in Syria, the annual cost for heating and cooling of a chicken farm was reduced by $69.2 \%$ compared to a conventional coal heater and ASHP air conditioner. In the same study, the COP of a typical ASHP and GSHP system was compared in a Syrian climate. For heating and cooling, the COP for the ASHP was 4 and 4.3, respectively, while for the GSHP the COP was 6.2 for heating and 10 for cooling.

Another common type of GSHP system is the so called shallow GSHP, where the heat carrier circulates inside closed collector loops, typically placed horizontally in the top 3 meters of the ground. The passively stored thermal solar energy in the topsoil layers of the ground is thereby used for heating purposes during winter. Cooling is achieved by releasing excess heat to the ground. In climates with negligible risk of frozen ground, water can be used as heat carrier fluid in the ground, thereby eliminating the risk of ground pollution in case of pipe ruptures.

The primary difference in the shallow ground source system and the BTES is that the former are most suitable in locations with wet soils of low permeability, where the thermal conductivity is relatively high around the collector pipes, while BTES is installed where the bedrock is shallow and robust. The installation cost in shallow ground source heat pump systems are also generally less than in BTES coupled with heat pumps, but the required ground area is on the other hand considerably larger. The heat pumps used in combination with both BTES and shallow ground source systems are, however, usually of the same capacity and functionality.

Where the geohydrological and demographic situation is found suitable, Aquifer Thermal Energy Storage (ATES) systems can be used for cooling and/or heating purposes. These systems usually require one set of cold wells and another set of warm wells in the aquifer. A small scale ATES may consist of only two wells, one cold and one warm. During winter, the cold wells are charged with outside natural cold, using cooling towers, dry coolers, or waste cold water from heat pumps generating heat [20] [21]. Warmer water is simultaneously withdrawn from the warm wells at the same pumping rate. When cooling is required, the pumping is reversed so that cold water is extracted from the cold wells, and warmer water is injected into the warm wells.

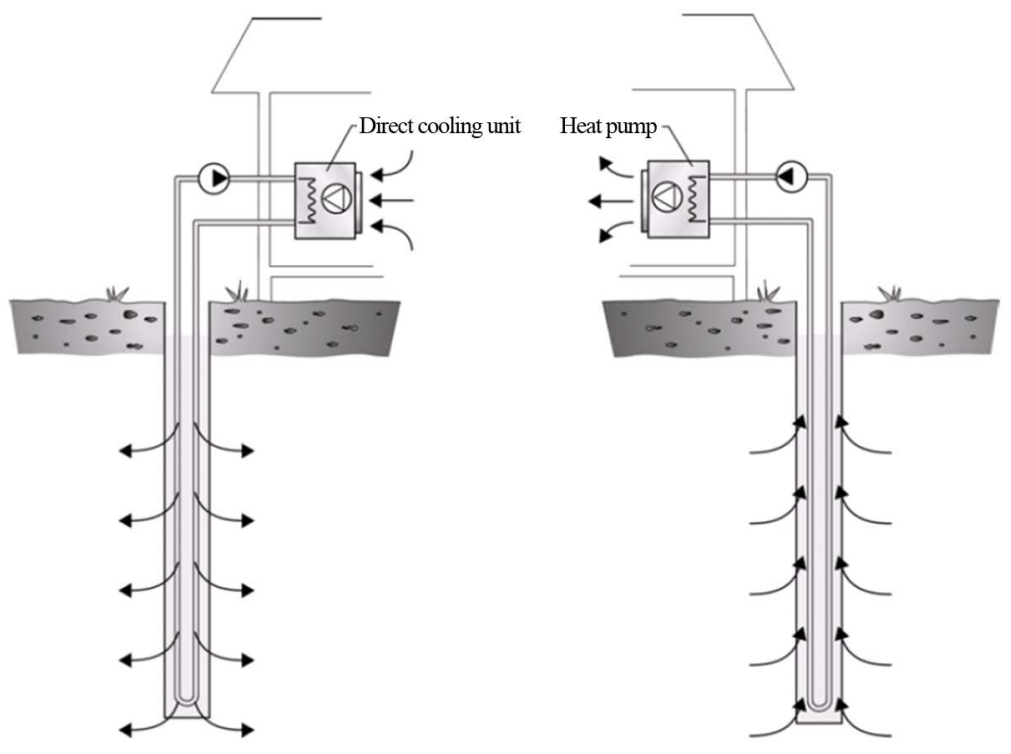

Figure 15. Simple bore hole storage connected to a heat pump for domestic space heating and cooling [19]. 


\section{Conclusion}

GSHP and ATES have a great potential to improve both the energy market and the environment in Middle Eastern countries in order to promote the technology in this region of the world; test facilities and pilot plants should be constructed and evaluated. There are several software products available for analyzing different types of designs. If site specific designs are to be possible, in-situ measurements must also be conducted. It is believed that using this technique for cooling and heating purposes will reduce electricity consumption by at least $60 \%$.

\section{References}

[1] The Economist (2014) Electricity in Iraq Not Yet Switched on, in Any Way. http://www.economist.com/blogs/pomegranate/2014/03/electricity-iraq

[2] Ifpinfo.com (2013) Iraq’s Electricity Capacity Reaches 10000 MW. http://www.ifpinfo.com/Top-MiddleEast-NewsArticle-3038\#.VmNzMqMV-Ai

[3] Al-Salhy, S. (2015) Shortage of Electricity in Iraq Cripples Economy, Sparks Protests, Middle East Eye. http://www.middleeasteye.net/news/shortage-electricity-cripples-economy-and-sparks-demonstrations-iraq-58980501

[4] Al-Katteeb, L. and Istepanian, H. (2015) Turn a Light on: Electricity Sector in Iraq, Brookings Doha Center. http://www.brookings.edu/ /media/research/files/papers/2015/03/18-electricity-sector-reform-iraq-alkhatteeb-istepania n/alkhatteeb-istepanian-english-pdf.pdf

[5] Almintor (2015) Iraq Pulse, Never-Ending Electricity Crisis Means Lights out for Iraqis, Again. http://www.al-monitor.com/pulse/originals/2015/07/iraq-electricity-crisis-power-outages-daily-need-economy.html

[6] Iraq-Business News (2015) The Latest Electricity News from Iraq-Power Plants, Fuel, Construction and MoreBrought to You by Iraq Business News. http://www.iraq-businessnews.com/tag/electricity/

[7] Al Khalidy, K.S., Chabuk, A.J., Kadhim, M.M. (2012) Measurement of Lead Pollution in the Air of Babylon Governorate, Iraq during Year 2010. World Academy of Science, Engineering and Technology, 6, 830-833.

[8] Iraqi Ministry of Planning (2015) Records of Directorate of Census Babylon, Iraq.

[9] Iraqi Ministry of Municipalities and Public Works, Iraq (2009) Structural Plan of Babylon Governorate.

[10] Al-Jiburi, H.K. and Al-Basrawi, N.H. (2011) Hydrogeology of the Mesopotamia Plain. Iraqi Bulletin of Geology and Mining, Special Issue, No. 4, 83-103.

[11] Araim, H.I. (1990) Regional Hydrogeology of Iraq, GEOSURV, Internal Report No. 1450.

[12] Al-Jiburi, H.K. (2002) Hydrogeological and Hydrochemical Study of Karbala Quadrangle (NI-38-14), Scale 1:250000. GEOSURV, Internal Report No. 2825.

[13] Kharseh, M. and Nordell, B. (2009) First Thermal Response Test in Syria. IS. Gehlin (Redaktör), Abstract Book and Proceedings: Effstock 2009: 11th International Conference on Thermal Energy Storage for Energy Efficiency and Sustainability. Energi-Och Miljötekniska Föreningen/EMTF Förlag, Stockholm.

[14] Nordell, B. (1994) Borehole Heat Store Design Optimization. Doctoral Thesis, Luleå University of Technologyy, Luleåtekniskauniversitet, Luleå.

[15] Kharseh, M. (2009) Reduction of Prime Energy Consumption in the Middle East by GSHP Systems. Licentiate Thesis, Luleå University of Technology, Luleåtekniskauniversitet, Luleå.

[16] Hellström, G. (2008) Large-Scale Applications of Ground-Source Heat Pumps in Sweden. IEA Heat Pump Annex 29 Workshop, Zurich.

[17] Nordell, B., Grein, M. and Kharseh, M. (2007) Large-Scale Utilisation of Renewable Energy Requires Energy Storage. Artikelnharpresenterats vid International Conference for Renewable Energies and Sustainable Developement, Tlemcen, Algeriet.

[18] Bergvärmepumpar (2014) http://www.energimyndigheten.se/hushall/testerresultat/testresultat/bergvarmepumpar-november-2012/

[19] Gehlin, S. (2002) Thermal Response Test: Method Development and Evaluation. Doctoral Thesis, Luleå University of Technology, Luleåtekniskauniversitet, Luleå.

[20] Kharseh, M. (2011) Reduction of Prime Energy Consumption by Ground Source Heat Pumps in a Warmer World. Doctoral Thesis, Luleå University of Technology, Luleåtekniskauniversitet, Luleå.

[21] Nordell, B., Snijders, A. and Stiles, L. (2015) The Use of Aquifers as Thermal Energy Storage (TES) Systems. Advances in Thermal Energy Storage Systems. Woodhead Publishing. 